Dinamika Kesehatan Jurnal Kebidanan dan Keperawatan Vol 10 No. 1 Juli 2019 (ISSN: 2086-3454 EISSN: 2549-4058) url: http://ojs.dinamikakesehatan.unism.ac.id DOI : https://doi.org/10.33859/dksm.v10i1

Efektifitas Relaksasi Genggam Jari Terhadap Penurunan Nyeri Pada Pasien Post Op Appendiktomi di Ruang Bedah (Al-Muizz) RSUD Ratu Zalecha Martapura Tahun 2019

\title{
Efektifitas Relaksasi Genggam Jari Terhadap Penurunan Nyeri Pada Pasien \\ Post Op Appendiktomi di Ruang Bedah (Al-Muizz) \\ RSUD Ratu Zalecha Martapura Tahun 2019
}

\author{
Asni Hasaini \\ Akper Intan Martapura \\ Martapura, Kalimantan Selatan Indonesia \\ Korespondensi Email : asnihasaini87@gmail.com
}

DOI: https://doi.org/10.33859/dksm.v10i1.394

\begin{abstract}
Abstrak
Latar Belakang: Prevalensi apendesitis akut yang menjalani appendiktomy sebanyak 75,2\% dan keluhan yang sering dirasakan adalah nyeri yang sangat hebat, sedang sampai ringan. Nyeri akan berdampak pada aktivitas sehari-hari, dan apabila tidak ditangani dapat mengakibatkan syok neurogenik. Sehingga diperlukan tindakan keperawatan mandiri dengan melakukan manajemen nyeri yang sederhana dan mudah untuk dilakukan yaitu relaksasi genggam jari.

Tujuan: Untuk menganalisis efektifitas relaksasi genggam jari terhadap penurunan nyeri pada pasien post op appendiktomy di Ruang Bedah (Al-Muizz) RSUD Ratu Zalecha Martapura.

Metode: Jenis desain penelitian adalah metode eksperimental dengan rancangan one-group pre-post test design. Populasi adalah seluruh klien yang terdiagnosa Post Op Appendictomy dan sampel sebanyak 15 orang responden dengan simple random sampling. Instrument menggunakan lembar observasi dan dianalisis bivariat dengan Wilcoxon.

Hasil: Ada efek relaksasi genggam jari terhadap penurunan nyeri pada pasien post op appendiktomy di Ruang Bedah (Al-Muizz) RSUD Ratu Zalecha Martapura $\mathrm{p}=0,000(\mathrm{p}<0,05)$.

Kesimpulan: Tingkat nyeri sebelum diberikan relaksasi genggam jari didapatkan dikategori nyeri sedang, dan sesudah diberikan dikategorikan nyeri ringan. Hasil analisis sebelum dan sesudah dilakukan relaksasi genggam jari didapatkan $\mathrm{p}=0,000(\mathrm{p}<0,05)$ maka $\mathrm{H}_{0}$ ditolak yang artinya ada pengaruh (signifikan) Ada efek relaksasi genggam jari terhadap penurunan nyeri pada pasien post op appendiktomy di Ruang Bedah (Al-Muizz) RSUD Ratu Zalecha Martapura.
\end{abstract}

Kata kunci: Relaksasi Genggam Jari, Nyeri, Post Op Appendiktomy 
Dinamika Kesehatan Jurnal Kebidanan dan Keperawatan Vol 10 No. 1 Juli 2019 (ISSN: 2086-3454 EISSN: 2549-4058) url: http://ojs.dinamikakesehatan.unism.ac.id DOI : https://doi.org/10.33859/dksm.v10i1

Efektifitas Relaksasi Genggam Jari Terhadap Penurunan Nyeri Pada Pasien Post Op Appendiktomi di Ruang Bedah (Al-Muizz) RSUD Ratu Zalecha Martapura Tahun 2019

\title{
The Effectiveness of Finger Grip Relaxation Against the Pain Reduction of Post Op Appendictomy Patients in the Surgical Room (Al-Muizz) RSUD Ratu Zalecha Martapura 2019
}

\begin{abstract}
Background: The prevalence of acute appendicitis undergoing appendictomy is $75.2 \%$ and complaints that are often felt are very severe, moderate to mild pain. Pain will have an impact on daily activities, and if left untreated can lead to neurogenic shock. So that independent nursing action is needed by doing pain management that is simple and easy to do, namely hand-held relaxation.

Objective: To analyze the effectiveness of finger grip relaxation against the pain reduction on post op appendictomy patients in the Surgical Room (Al-Muizz) RSUD Ratu Zalecha Martapura.

Method: The type of research design is an experimental method with a one-group pre-post test design. The population is all clients who are diagnosed with Post Op Appendictomy and sample is taken from 15 respondents with simple random sampling. The Instrumentuses observation sheets and will be analyzed by using bivariate with Wilcoxon.

Results: There is an effect of the effectiveness of finger grip relaxation on the pain reduction of post op appendictomy patients in the Surgical Room (Al-Muizz) RSUD Ratu Zalecha Martapura p=0,000 $(p<0,05)$.

Conclusion: The pain level before the finger grip relaxationgiven was categorized medium pain, and after it was given, the pain level turned into mild category. The results before and after the finger grip is $p=0,000(p<0,05)$ then $H_{0}$ was rejected which means there is an influence (significant) of the finger grip relaxation on the pain reduction of the Post Op Appendictomypatients in the Surgical Room (Al-Muizz) RSUD Ratu Zalecha Martapura.
\end{abstract}

Key words: Finger Grip Relaxation, Pain, Post Op Appendictomy. 
Dinamika Kesehatan Jurnal Kebidanan dan Keperawatan Vol 10 No. 1 Juli 2019 (ISSN: 2086-3454 EISSN: 2549-4058) url: http://ojs.dinamikakesehatan.unism.ac.id DOI : https://doi.org/10.33859/dksm.v10i1

Efektifitas Relaksasi Genggam Jari Terhadap Penurunan Nyeri Pada Pasien Post Op Appendiktomi di Ruang Bedah (Al-Muizz) RSUD Ratu Zalecha Martapura Tahun 2019

\section{PENDAHULUAN}

Menurut Wime De Jong et al. (2005) Apendicitis adalah salah satu kasus bedah abdomen yang paling sering terjadi. Apendisitis merupakan peradangan akibat infeksi pada usus buntu atau umbai cacing (apendiks). Usus buntu sebenarnya adalah sekum (сесum). Infeksi ini bisa mengakibatkan peradangan akut sehingga memerlukan tindakan bedah segera untuk mencegah komplikasi yang umumnya berbahaya. (Hardhi K, Amin H,N. 2015).

Menurut Potter \& Perry (2014) salah satu untuk tindakan pasien apendiks akut adalah dengan cara pembedahan atau yang disebut appendiktomy yang merupakan tindakan invasif dengan membuka bagian tubuh yang akan ditangani, pembukaan ini umumnya dilakukan dengan sayatan, pada pembedahan appendiktomy, insisi McBurney paling banyak dipilih oleh ahli bedah. Serta keluhan yang sering dirasakan setelah pembedahan (pasca operasi) pasien merasakan nyeri yang sangat hebat, sedang sampai ringan dan mempunyai pengalaman yang kurang menyenangkan akibat nyeri yang tidak adekuat. (Sulung N, Dian Rani S, 2017).

Menurut WHO (2010) angka mortalitas akibat apendisitis cukup tinggi didunia pada laki-laki 21.000 jiwa, dibandingkan pada perempuan 10.000 jiwa. Pada tahun 2013 (WHO) menganalisa data Nasional antara tahun 2011 sampai 2012 terdapat 32.782 pasien menderita apendesitis akut yang menjalani appendiktomy sebanyak 75,2\%. (Sulung N, Dian Rani S, 2017).

Menurut Utami, (2014) di asia insiden apendisitis pada tahun 2013 adalah 48\% penduduk dari total populasi. Sedangkan dari hasil survey Kesehatan Rumah Tangga (SKRT) di indonesia, insiden apendisitis di Indonesia memiliki urutan tertinggi, pada tahun 2013 jumlah penderita apendisitis di Indonesia mencapai 591.819 orang dan meningkat pada tahun 2014 sebesar 596.132 orang. (Sulung N, Dian Rani S, 2017).

Berdasarkan Data Dari Dinas Kesehatan tahun 2017 Kejadian apendisitis yang menjalani appendiktomy bersifat fluktuatif 
Dinamika Kesehatan Jurnal Kebidanan dan Keperawatan Vol 10 No. 1 Juli 2019 (ISSN: 2086-3454 EISSN: 2549-4058) url: http://ojs.dinamikakesehatan.unism.ac.id DOI : https://doi.org/10.33859/dksm.v10i1

Efektifitas Relaksasi Genggam Jari Terhadap Penurunan Nyeri Pada Pasien Post Op Appendiktomi di Ruang Bedah (Al-Muizz) RSUD Ratu Zalecha Martapura Tahun 2019

karena pada tahun 2016 jumlah penderita apendisitis 101 penderita dan mengalami penurunan pada tahun 2017 yaitu 78 penderita. (Dinkes provinsi Kalsel, 2017).

Berdasarkan data yang diambil dari Rekam Medik RSUD Ratu Zalecha Martapura Tahun 2018, dari bulan April sampai Oktober terhitung 34 pasien. Pada studi pendahuluan, melalui wawancara dengan pasien post op Appendiktomy di Ruang Bedah (Al-Muizz) RSUD Ratu Zalecha Martapura pada tanggal November 2018 kepada 10 responden didapatkan 8 orang $(80 \%)$ mengalami nyeri dengan skala 4 (nyeri sedang), dan 2 orang (20\%) mengalami nyeri dengan skala 2 (nyeri ringan). $100 \%$ dari responden mengatakan tidak mengetahui cara mengatasi nyeri selain meminum obat yang diberikan dari dokter.

Menurut Gannong, (2008) pada umumnya post operasi appendiktomy mengalami nyeri akibat bedah luka operasi. Seseorang yang mengalami nyeri akan berdampak pada aktivitas sehari-hari seperti pemenuhan kebutuhan istirahat tidur, pemenuhan individu, juga aspek interaksi sosial (menghindari percakapan, menarik diri dan menghindari kontak), dan apabila tidak ditangani dapat mengakibatkan syok neurogenik. (Virgianti N.F, 2015).

Diharapkan dengan tindakan asuhan keperawatan penanganan nyeri yang menggunakan manajemen nyeri yang mempunyai beberepa tindakan atau prosedur baik secara farmakologis maupun non farmakologis. Tindakan secara farmakologis dilakukan dengan memberikan analgesik, ialah untuk mengurangi atau menghilangkan rasa nyeri. Sedangkan tindakan secara non farmakologis dapat dilakukan dengan cara relaksasi, tekhnik nafas dalam, perubahan posisi, massage, terapi panas dingin. (Virgianti N.F, 2015).

Menurut Chanif, Petpichetchin \& Chongchaeron (2013) Salah satu dari tindakan pengobatan non farmakologi yang dapat dilakukan adalah teknik relaksasi genggam jari, yang dimana teknik ini mudah digunakan oleh siapapun yang berhubungan dengan jari tangan dan aliran energi didalam tubuh, terdapat kombinasi yaitu relaksasi nafas 
Dinamika Kesehatan Jurnal Kebidanan dan Keperawatan Vol 10 No. 1 Juli 2019 (ISSN: 2086-3454 EISSN: 2549-4058) url: http://ojs.dinamikakesehatan.unism.ac.id DOI : https://doi.org/10.33859/dksm.v10i1

Efektifitas Relaksasi Genggam Jari Terhadap Penurunan Nyeri Pada Pasien Post Op Appendiktomi di Ruang Bedah (Al-Muizz) RSUD Ratu Zalecha Martapura Tahun 2019

dalam, menggunakan waktu yang relatif singkat. Teknik tersebut merupakan cara untuk mengelola emosi dan mengembangkan kecerdasan esmosional. Di sepanjang jari-jari terdapat saluran yang terhubung dengan berbagai organ dan emosi. Titik-titik refleksi pada tangan memberikan rangsangan secara spontan pada saat genggaman. Rangsangan tersebut akan mengalirkan semacam gelombang kejut atau listrik ke otak. Gelombang tersebut diterima otak dan diproses dengan cepat diteruskan menuju saraf pada organ tubuh yang mengalami gangguan, sehingga sumbatan dijalur energi menjadi lancar. Teknik relaksasi genggam jari dengan tindakan asuhan keperawatan penanganan nyeri yang menggunakan manajemen nyeri yang mempunyai beberepa tindakan Dalam keadaan relaksasi secara alamiah akan memicu pengeluaran hormon endorphin, hormon ini ialah analgesik alami tubuh sehingga nyeri akan berkurang. (Sulung N, Dian Rani S, 2017).

\section{METODE}

Desain penelitian yang digunakan adalah metode eksperimental yang menggunakan pendekatan atau rancangan one-group pre-post test design dimana pendekatan ini adalah mengungkapkan hubungan sebab akibat dengan cara melibatkan suatu subjek. Populasi dalam penelitian ini adalah seluruh klien yang terdiagnosa Post Op Appendictomy di Ruang Bedah (Al-Muizz) RSUD Ratu Zalecha Martapura sebanyak 43 responden, dan sampel dalam penelitian ini berjumlah 15 orang responden. Teknik pengumpulan sampel menggunakan simple random sampling. Kriteria inklusi adalah : 1) Pasien di Ruang Bedah (Al-Muizz) RSUD Ratu Zalecha Martapura, Pasien post op appendiktomy yang mengalami nyeri sedang dan ringan, 3) 7-8 jam setelah pemberian analgetik, 4) Pasien yang sadar penuh (compos mentis). 5) Pasien yang bersedia menjadi responden. Variabel dalam penelitian ini variabel independen pada adalah Relaksasi 
Dinamika Kesehatan Jurnal Kebidanan dan Keperawatan Vol 10 No. 1 Juli 2019 (ISSN: 2086-3454 EISSN: 2549-4058) url: http://ojs.dinamikakesehatan.unism.ac.id DOI : https://doi.org/10.33859/dksm.v10i1

Efektifitas Relaksasi Genggam Jari Terhadap Penurunan Nyeri Pada Pasien Post Op Appendiktomi di Ruang Bedah (Al-Muizz) RSUD Ratu Zalecha Martapura Tahun 2019

Genggam Jari yang dilakukan sekitar 30-40

menit. Variabel dependen adalah penurunan

nyeri yang diukur menggunakan Skala

intensitas nyeri deskriptif sederhana.

\section{HASIL}

1. Karasteristik Responden

a. Jenis Kelamin

Tabel 1. Distribusi Frekuensi Berdasarkan Jenis Kelamin Pasien Post Op Appendictomy di Ruang Bedah (AlMuizz) RSUD Ratu Zalecha Martapura Tahun $2019(\mathrm{n}=15)$

Jenis Kelamin Frekuensi Presentase

Laki-Laki $\quad 9 \quad 60$

\begin{tabular}{lll} 
Perempuan & 6 & 40 \\
\hline
\end{tabular}

\begin{tabular}{lrr} 
Total & 15 & 100 \\
\hline
\end{tabular}

Berdasarkan hasil tabel 1 di atas

didapatkan jenis kelamin terbanyak pada pasien Post Op Appendictomy di Ruang Bedah (Al-Muizz) RSUD Ratu Zalecha adalah laki-laki sebanyak 9 orang (60\%).

\section{Data Khusus Responden}

a. Nyeri pada pasien post op Appendiktomy sebelum dilakukan relaksasi genggam jari di Ruang Bedah RSUD Ratu Zalecha Martapura Tahun 2019.
Tabel 2. Skala nyeri sebelum dilakukan Relaksasi Genggam Jari pada Pasien Post Op Appendiktomy, $\mathrm{N}=15$ di Ruang Bedah RSUD Ratu Zalecha Martapura Tahun $2019(\mathrm{n}=15)$

\begin{tabular}{|c|c|c|c|c|}
\hline Mean & Median & Max & Min & $\begin{array}{c}\text { Standar } \\
\text { Deviasi }\end{array}$ \\
\hline 4 & 4 & 5 & 3 & 0,535 \\
\hline
\end{tabular}

Berdasarkan data tabel 2. Tingkat nyeri sebelum diberikan relaksasi genggam jari pada 15 responden di dapatkan tingkat nyeri rerata 4 dikategori nyeri sedang, nilai tertinggi nyeri adalah 5, dan nilai terendah nyeri adalah 3 , dengan standar deviasi sebesar 0,535.

b. Nyeri pada pasien post op Appendiktomy sesudah dilakukan relaksasi genggam jari di Ruang Bedah RSUD Ratu Zalecha Martapura Tahun 2019

Tabel 3. Skala Nyeri sesudah dilakukan Relaksasi Genggam Jari pada Pasien Post Op Appendiktomy, $\mathrm{N}=15$ di Ruang Bedah RSUD Ratu Zalecha Martapura Tahun $2019(n=15)$

\begin{tabular}{|c|c|c|c|c|}
\hline Mean & Median & Max & Min & $\begin{array}{c}\text { Standar } \\
\text { Deviasi }\end{array}$ \\
\hline 1.73 & 2 & 2 & 1 & 0,458 \\
\hline
\end{tabular}

Berdasarkan data tabel 2. Tingkat nyeri sesudah diberikan relaksasi genggam jari pada 15 responden didapatkan tingkat nyeri rerata (1.73) dikategori nyeri ringan, nilai tertinggi nyeri adalah 2, nilai 
Dinamika Kesehatan Jurnal Kebidanan dan Keperawatan Vol 10 No. 1 Juli 2019 (ISSN: 2086-3454 EISSN: 2549-4058) url: http://ojs.dinamikakesehatan.unism.ac.id DOI : https://doi.org/10.33859/dksm.v10i1

Efektifitas Relaksasi Genggam Jari Terhadap Penurunan Nyeri Pada Pasien Post Op Appendiktomi di Ruang Bedah (Al-Muizz) RSUD Ratu Zalecha Martapura Tahun 2019

terendah nyeri adalah 1 dengan standar

deviasi sebesar 0,438 .

b. Analisa Bivariat

Efek Pemberian Terapi Relaksasi Genggam Jari Terhadap Penurunan Tingkat Nyeri Pada Pasien Post Op Appendiktomy Di Ruang Bedah RSUD Ratu Zalecha Martapura Tahun 2019.

Tabel 4. Efek sebelum dan sesudah diberikan Teknik Relaksasi Genggam Jari terhadap Penurunan Tingkat Nyeri pada Pasien Post Op Appendiktomy di Ruang Bedah RSUD Ratu Zalecha Martapura Tahun 2019 $(n=15)$

\begin{tabular}{|c|c|c|c|c|}
\hline Mean & Median & Max & Min & $\begin{array}{c}\text { Standar } \\
\text { Deviasi }\end{array}$ \\
\hline 2.27 & 2 & 3 & 1 & 0,77 \\
\hline
\end{tabular}

Berdasarkan tabel 4. Perbedaan nyeri tingkat post op appendiktomy sebelum dan sesudah diberikan relaksasi genggam jari pada 15 responden di dapatkan rerata perubahan

\section{2,27 tingkat ringan.}

Berdasarkan hasil uji statistik dengan menggunakan Wilcoxon diperoleh nilai $\mathrm{p}=$ 0,000. Dengan nila $p<0,05$, maka Ha diterima yang artinya ada efek antara pemberian relaksasi genggam jari terhadap penurunan tingkat nyeri pada pasien Post Op
Appendiktomy Di Ruang Bedah RSUD Ratu

Zalecha Martapura Tahun 2019.

\section{PEMBAHASAN}

1. Tingkat nyeri sebelum dilakukan terapi relaksasi genggam jari di Ruang Bedah RSUD Ratu Zalecha Martapura Tahun 2019.

Berdasarkan distribusi frekuensi responden sebelum relaksasi genggam jari terhadap penurunan tingkat nyeri pada 15 orang didapatkan hasil tingkat nyeri insisi post op appendiktomy rerata 4 dikategori nyeri sedang.

Intensitas nyeri pada responden dipengaruhi beberapa faktor salah satunya adalah kondisi psikologis adalah faktor dominan yang mempengaruhi intensitas nyeri yang dirasakan pada pasien dengan post-appendectomy di mana efek dari nyeri akut, pasien menjadi cemas dan tidak mampu mengendalikan rasa sakit. Wanita yang lebih cenderung mengalami kecemasan dapat meningkatkan rasa sakit dibandingkan pria, berdasarkan tabel 1 
Dinamika Kesehatan Jurnal Kebidanan dan Keperawatan Vol 10 No. 1 Juli 2019 (ISSN: 2086-3454 EISSN: 2549-4058) url: http://ojs.dinamikakesehatan.unism.ac.id DOI : https://doi.org/10.33859/dksm.v10i1

Efektifitas Relaksasi Genggam Jari Terhadap Penurunan Nyeri Pada Pasien Post Op Appendiktomi di Ruang Bedah (Al-Muizz) RSUD Ratu Zalecha Martapura Tahun 2019

responden dominan laki-laki sebesar $60 \%$.

Ini karena wanita merasa lebih peka terhadap masalah, sehingga lebih banyak mekanisme koping wanita kurang baik daripada pria (Smeltzer \& Bare, 2002). Kecemasan akan mengakibatkan kondisi cedera pasien dan perawatan siang hari yang panjang di rumah sakit sehingga perawat harus menjelaskan penyebab rasa sakit dan cara menguranginya. Namun dalam penelitian ini tidak dapat disimpulkan bahwa intensitas nyeri pada pria lebih rendah daripada wanita karena keterbatasan responden gender pria.

$$
\text { Appendiktomy merupakan }
$$

pembedahan dengan membuka bagian tubuh dengan membuat sayatan, pembedahan appendiktomy terbuka untuk mengangkat apendiks yang meradang. Nyeri yang dirasakan oleh pasien post opappendiktomy berbeda-beda, terbukti dari hasil penelitian dilihat nyeri dengan skala 5 di alami 2 orang dan nyeri dengan skala 4 di alami 11 orang dan nyeri dengan skala 3 di alami oleh 2 orang .
Dari distribusi tabel 1 dapat dilihat bahwa nyeri berada pada kisaran tingkat 3 sampai tingkat 5 yaitu berada pada kategori mulai dari ringan sampai sedang. Hal ini seperti pendapat Molyono (2008) yang mengemukakan bahwa pasien akan merasakan nyeri sedang hingga hebat setelah operasi karena pengaruh obat anastesi sudah hilang, dan penelitian yang dilakukan oleh Andika \& Musthafa (2016) lebih dari setengah $(60,0 \%)$ tingkat nyeri sebelum dilakukan relaksasi genggam jari pada pasien post op appendiktomy berada pada kategori sedang.

\section{Tingkat nyeri sesudah dilakukan terapi} relaksasi genggam jari di Ruang Bedah RSUD Ratu Zalecha Martapura Tahun 2019.

Berdasarakan distribusi frekuensi responden setelah diajarkan teknik relaksasi genggam jari terhadap penurunan tingkat nyeri pada 15 orang didapatkan hasil nyeri insisi post op appendiktomy rerata $(1,73)$ dikategori nyeri ringan. 
Dinamika Kesehatan Jurnal Kebidanan dan Keperawatan Vol 10 No. 1 Juli 2019 (ISSN: 2086-3454 EISSN: 2549-4058) url: http://ojs.dinamikakesehatan.unism.ac.id DOI : https://doi.org/10.33859/dksm.v10i1

Efektifitas Relaksasi Genggam Jari Terhadap Penurunan Nyeri Pada Pasien Post Op Appendiktomi di Ruang Bedah (Al-Muizz) RSUD Ratu Zalecha Martapura Tahun 2019

Pengurangan intensitas rasa sakit

pada pasien dengan Post-Appendectomy karena terapi relaksasi jari tangan membantu responden untuk rileks dengan memegang masing-masing dari lima jari satu per satu, sekitar 3 hingga 5 menit dari emosi lama yang paling sederhana dan mudah untuk melepaskan emosi dan membantu orang bersantai. Teknik ini memberikan sentuhan tangan dan pernapasan yang mudah untuk keseimbangan energi dalam tubuh (Liana, 2008). Secara fisiologis, teknik relaksasi jari tangan dapat mengurangi rasa sakit. Stimulasi nyeri menyebabkan pelepasan mediator responden, rasa sakit yang ditransmisikan oleh delta-serat $\mathrm{A}$ dan $\mathrm{C}$, impuls sepanjang serabut saraf yang dibawa ke substansia aferen gelatinosa aferen (gerbang) di sumsum tulang belakang untuk melewati berikutnya melalui thalamus dan kemudian dikirim ke korteks serebral dan diartikan sebagai rasa sakit. Perawatan relaksasi genggam dengan jari akan menghasilkan impuls yang dikirim melalui serabut saraf aferen non-nosiseptor yang mengarah ke "gerbang" yang ditutup sebagai akibat dari input dominan dari serat A-beta yang mensekresi inhibitor neurotransmitter yang menghambat dan mengurangi stimulus nyeri. Gerbang dapat ditemukan di sel-sel agar-agar di ujung sumsum tulang belakang, thalamus dan otak kecil. Dengan demikian, perawat dapat memperoleh kerangka kerja konseptual yang berguna untuk pengelolaan nyeri. Teori ini menyatakan bahwa stimulus akan terhambat ketika pintu ditutup. Penutupan pintu adalah dasar untuk terapi pereda nyeri (Potter \& Perry, 2005). Demikian pula, Suhartini (2007) mengatakan bahwa rasa sakit adalah mekanisme untuk produksi tubuh, yang terjadi ketika jaringan sedang rusak dan menyebabkan individu bereaksi atau menghilangkan rangsangan rasa sakit. Menurut penelitian yang dilakukan Pinandita. et al, intensitas nyeri pada responden setelah menerima perawatan 
Dinamika Kesehatan Jurnal Kebidanan dan Keperawatan Vol 10 No. 1 Juli 2019 (ISSN: 2086-3454 EISSN: 2549-4058) url: http://ojs.dinamikakesehatan.unism.ac.id DOI : https://doi.org/10.33859/dksm.v10i1

Efektifitas Relaksasi Genggam Jari Terhadap Penurunan Nyeri Pada Pasien Post Op Appendiktomi di Ruang Bedah (Al-Muizz) RSUD Ratu Zalecha Martapura Tahun 2019

teknik pegangan jari / genggam akan berubah atau mengalami modulasi akibat stimulasi relaksasi jari tangan yang pertama dan lebih mencapai otak sehingga menghambat stimulasi rasa sakit ke otak.

Menurut Pinandita (2012) Teknik relaksasi genggam jari merupakan salah satu teknik relaksasi yang menggunakan jari tangan yang membuat responden mengalami penuruan nyeri sesudah teknik relaksasi genggam jari karena teknik ini memberikan suatu tindakan untuk membebaskan mental dan fisik dari ketegangan stress sehingga dapat meningkatkan toleransi terhadap nyeri. Hal ini sesuai dengan teori yang dikatan pinandita bahwa Relaksasi genggam jari menghasilkan impulse yang dikirim melalui serabut saraf aferen nonnosiseptor. serabut saraf aferen nonnosiseptor mengakibatkan "gerbang" tertutup sehingga stimulus nyeri terhambat dan berkurang. Sehingga intensitas nyeri akan berubah atau mengalami modulasi akibat stimulasi relaksasi genggam jari yang terlebih dahulu dan lebih banyak mencapai otak. (Astutik P, Kurlinawati E, 2017)

Dikuatkan dalam jurnal sari \& maliya (2015), yang menyatakan menggenggaam jari sambil menarik nafas dalam dapat mengurangi ketegangan fisik karena dapat menghangatkan titik-titik masuk dan keluarnya energy pada meridian yang berhubungan dengan organ-organ didalam tubuh yang terletak pada jari tangan. Titiktitik refleksi pada tangan memberikan rangsangan secara refleks pada saat genggaman. Rangsangan tersebut akan mengalirkan semacam gelombang kejut menuju otak kemudian diproses dengan cepat kemudian diteruskan menuju saraf pada organ tubuh yang mengalami gangguan sehingga sumbatan dijalur energi jadi lancar. 
Dinamika Kesehatan Jurnal Kebidanan dan Keperawatan Vol 10 No. 1 Juli 2019 (ISSN: 2086-3454 EISSN: 2549-4058) url: http://ojs.dinamikakesehatan.unism.ac.id DOI : https://doi.org/10.33859/dksm.v10i1

Efektifitas Relaksasi Genggam Jari Terhadap Penurunan Nyeri Pada Pasien Post Op Appendiktomi di Ruang Bedah (Al-Muizz) RSUD Ratu Zalecha Martapura Tahun 2019

3. Efek sebelum dan sesudah Pemberian

Terapi Relaksasi Genggam Jari

Terhadap Penurunan Tingkat Nyeri

Pada Pasien Post Op Appendiktomy Di

Ruang Bedah RSUD Ratu Zalecha

Martapura Tahun 2019.

Berdasarkan tabel 3. Hasil analisis sebelum dan sesudah dilakukan relaksasi genggam jari terhadap penurunan tingkat nyeri pada pasien post op appendiktomy sebanyak 15 orang dengan hasil rerata 2,27 dikategorikan nyeri ringan. Hasil uji statistik menggunakan Wilcoxon diperoleh nilai $p=0,000$. Dengan nilai $p<$ 0,05 , maka Ha diterima yang artinya ada efek antara pemberian teknik relaksasi genggam jari terhadap penurunan tingkat nyeri post op appendiktomy Di Ruang Bedah RSUD Ratu Zalecha Martapura Tahun 2019.

Teknik relaksasi jari genggam adalah strategi manajemen nyeri yang efektif pada hari pertama pasien pascaappendektomi karena dapat dilihat penurunan intensitas nyeri, perawat juga sangat diperlukan dalam upaya manajemen nyeri non farmakologis untuk mengurangi intensitas nyeri. Teknik Relaksasi Jari Genggam Dalam penelitian ini, responden diberikan perlakuan teknik relaksasi jari genggam yang dilakukan selama 30-50 menit. Berdasarkan hasil penelitian secara umum tentang efek teknik relaksasi ini pada pasien PascaApendektomi ditemukan bahwa responden yang mengalami perbedaan intensitas nyeri, ini berarti bahwa responden yang diberikan jari tangan untuk teknik relaksasi dapat merasakan kegembiraan ketika disentuh. Stimulus ini membuat responden merasa nyaman dan mengurangi sumber depresi dan kecemasan, sehingga rasa sakit dapat dikendalikan dan meningkatkan fungsi tubuh. Menurunnya intensitas nyeri terjadi pada responden setelah perawatan untuk teknik relaksasi jari memegang efek positif dari unsur-unsur yang dapat memberikan respons positif dan memadai, responden mampu merespon sentuhan jari 
Dinamika Kesehatan Jurnal Kebidanan dan Keperawatan Vol 10 No. 1 Juli 2019 (ISSN: 2086-3454 EISSN: 2549-4058) url: http://ojs.dinamikakesehatan.unism.ac.id DOI : https://doi.org/10.33859/dksm.v10i1

Efektifitas Relaksasi Genggam Jari Terhadap Penurunan Nyeri Pada Pasien Post Op Appendiktomi di Ruang Bedah (Al-Muizz) RSUD Ratu Zalecha Martapura Tahun 2019

yang ditunjukkan oleh penurunan level. rasa sakit (Liana, 2008). Efek Relaksasi Jari Genggam pada Pengurangan Intensitas Nyeri pada 57 Pasien dengan Post-Appendectomy di Ruang Rawat Inap, Rsud Sidoarjo Setiap pasien memiliki respons berbeda terhadap touchfelt dan diberikan kepada mereka. Ketika jaringan otot rileks, itu dapat meningkatkan sirkulasi darah dan getah bening, yang kemudian dapat menghilangkan asam laktat dalam serat otot dan mengurangi kelelahan dan stres. Ketika pasien rileks dan tidak stres menurunkan ketegangan otot yang akan mengurangi kecemasan. Impuls nyeri yang bisa diblokir adalah memberikan rangsangan pada saraf berdiameter besar yang menyebabkan gerbang kontrol akan ditutup dan tidak ada rangsangan nyeri yang dapat diteruskan ke korteks serebral dan kemudian nyeri akan berkurang (Mander, 2003). Hasil ini konsisten dengan pendapat Liana (2008) bahwa memegang jari dapat dilakukan sebagai alternatif manajemen nyeri non farmakologis pada pasien dengan keluhan nyeri dan dapat menghambat neurotransmitter nyeri untuk mentransmisikan impuls nyeri yang disebabkan oleh prosedur invasif. Memegang jari sambil bernapas dalamdalam (relaksasi) dapat mengurangi dan menyembuhkan ketegangan fisik dan emosional, karena itu akan menghangatkan titik-titik jari pada saat keluar dan masuknya energi meridian (saluran energi) yang terletak di jari-jari kita. Titik refleks pada tangan akan memberikan stimulasi refleks (spontan), rangsangan ini akan mengalir dalam gelombang listrik atau kejut ke otak. Gelombang diterima oleh otak dan diproses dengan cepat, lalu diteruskan ke saraf di organ tubuh yang terganggu, sehingga penyumbatan di jalur energi menjadi lancar. Aliran energi ini akan menghasilkan impuls yang dikirim melalui serabut saraf aferen yang mengakibatkan "gerbang" non-nosiseptor 
Dinamika Kesehatan Jurnal Kebidanan dan Keperawatan Vol 10 No. 1 Juli 2019 (ISSN: 2086-3454 EISSN: 2549-4058) url: http://ojs.dinamikakesehatan.unism.ac.id DOI : https://doi.org/10.33859/dksm.v10i1

Efektifitas Relaksasi Genggam Jari Terhadap Penurunan Nyeri Pada Pasien Post Op Appendiktomi di Ruang Bedah (Al-Muizz) RSUD Ratu Zalecha Martapura Tahun 2019

ditutup akibat input dominan dari serat Abeta yang mensekresikan inhibitor neurotransmitter yang menghambat dan mengurangi stimulus nyeri.

Penurunan rasa nyeri dapat terjadi ketika seseorang melakukan relaksasi genggam jari untuk menegndalikan nyeri yang dirasakan, maka tubuh akan meningkatkan komponen saraf parasimpatik secara stimulan, maka ini menyebabkan terjadinya kadar hormon adrenalin dalam tubuh yang mempengaruhi tingkat stress sehingga dapat meningkatkan konsentrasi tubuh mempermudah mengatur ritme pernafasan yang membuat meningkatkan kadar oksigen didalam darah memberikan rasa tenang yang mampu mengatasi nyeri. (Prasetyo, 2010).

Potter \& perry (2005) menyatakan bahwa teknik relaksasi genggam jari membuat pasien dapat menontrol diri dari rasa tidak nyaman atau nyeri, stress fisik atau emosi pada nyeri. Relaksasi juga dapat menurunkan sumber-sumber depresi dan kecemasan, sehingga nyeri dapat terkontrol dan fungsi tubuh semakin membaik. (Yuliasturi Christina, 2015).

\section{SIMPULAN}

1. Sebelum dilakukan relaksasi genggam jari terhadap penurunan tingkat nyeri post op appendiktomy, dikategorikan nyeri sedang dengan rerata 4 .

2. Sesudah dilakukan relaksasi genggam jari terhadap penurunan tingkat nyeri post op appendiktomy, dikategorikan nyeri ringa dengan rerata 1.73 .

3. Ada efek dari pemberian teknik relaksasi genggam jari terhadap penurunan nyeri pada pasien post op appendiktomy yang dimana didapat $p=0,000(p=0,000$ $<0,05)$, yang berarti Ha diterima, yang artinya ada efek peberian teknik relaksasi genggam jari terhadap penurunan nyeri pada pasien post op appendiktomy.

\section{SARAN}

1. Bagi pasien

Hasil penelitian teknik relaksasi genggam jari ini diharapkan dapat di terapkan 
Dinamika Kesehatan Jurnal Kebidanan dan Keperawatan Vol 10 No. 1 Juli 2019 (ISSN: 2086-3454 EISSN: 2549-4058) url: http://ojs.dinamikakesehatan.unism.ac.id DOI : https://doi.org/10.33859/dksm.v10i1

Efektifitas Relaksasi Genggam Jari Terhadap Penurunan Nyeri Pada Pasien Post Op Appendiktomi di Ruang Bedah (Al-Muizz) RSUD Ratu Zalecha Martapura Tahun 2019

sebagai tindakan mandiri untuk mengurangi nyeri pada pasien post op appendiktomy.

2. Bagi Rumah Sakit

Hasil penelitian ini dapat dijadikan sebagai sumber informasi dan referensi dalam melakukan tindakan komplementer untuk mengurangi rasa nyeri pada pasien post op Appendiktomy secara non farmakologi yaitu dengan pemberian teknik relaksasi genggam jari.

3. Bagi institusi pendidikan

Hasil penelitian ini diharapkan dapat memberikan pelajaran dalam rangka mengembangkan teori tentang relaksasi genggam jari terhadap penurunan nyeri pada pasien post op appendiktomy.

4. Bagi peneliti selanjutnya

Hasil penelitian ini diharapkan dapat menjadi bahan pertimbangan dan bahan pembelajaran untuk melakukan penelitian lebih lanjut mengenai efektiftas relaksasi genggam jari terhadap penurunan nyeri pada pasien post op Appendiktomy, misalnya dengan mengkombinasikkan relaksasi genggam jari dengan musik.

\section{DAFTAR PUSTAKA}

Afroh, F., Mohamad Judha, Sudarti (2012). Teori Pengukuran Nyeri \& Nyeri Persalinan, Yogyakarta: Nuha Medika.

Anas T (2014). Konsep Dan Penatalaksanaan Nyeri. Jakarta: EGC.

Andarmoyo (2013). Konsep dan Proses Keperawatan Nyeri. Editor Rose KR. Yogyakarta: Ar-Ruzz media. Di akses dari:http://repository.usu.ac.id/bit stream/123456789/44327/4/Chap terII.pdf. Pada Tanggal 23 Oktober 2018.

Arifudin A, Salmawati L, Prasetyo A. (2017). Jurnal Kesehatan Masyarakat, Vol.8, p.26-33.

Asmadi (2008). Teknik Prosedural Keperawatan Konsep dan Aplikasi Kebutuhan Dasar Klien. Jakarta: Salemba Medika

Astutik P, Kurlinawati E (2017). Pengaruh Relaksasi Genggam Jari Terhadap Penurunan Nyeri Pada Pasien Post Sectio Caesarea Di Ruang Delima RSUD Kertosono. Jurnal ilmiah kesehatan, Vol.6(2), p.30-37.

Berman, Audrey., Dkk. (2009). Buku Ajar Praktik Klinis Kozier \& Erb Edisi 5, Jakarta: EGC 
Dinamika Kesehatan Jurnal Kebidanan dan Keperawatan Vol 10 No. 1 Juli 2019 (ISSN: 2086-3454 EISSN: 2549-4058) url: http://ojs.dinamikakesehatan.unism.ac.id DOI : https://doi.org/10.33859/dksm.v10i1

Efektifitas Relaksasi Genggam Jari Terhadap Penurunan Nyeri Pada Pasien Post Op Appendiktomi di Ruang Bedah (Al-Muizz) RSUD Ratu Zalecha Martapura Tahun 2019

Christina Yuliasturi. (2005).” Effect Of Handheld Finger Relaxation On Reduction Of Pain Intensity In Patients With Post-Appendictomy At Inpatient Ward, Rsud Sidoarjo". International Journal of Medicine and Pharmaceutical Sciences (IJMPS)

Hardhi K, Amin H, N (2015). Aplikasi Asuhan Keperawatan Berdasarkan NANDA NIC-NOC. Edisi Revisi Jilid 1. Hal.47. Yogyakarta.

Harga, Silvia dan Wilson, Lorraine M. (2005). Patofisiologi Konsep Klinis Proses Penyakit, Edisi 6, Vol.3. Jakarta: EGC

Hidayat, A. Aziz Alimul (2008). Pengantar Konsep Dasar Keperawatan, Jakarta: Salemba Medika.

Hoaglund. (2009). Finger Hold, www.jarijaritangan.com diunduh pada tanggal 16 September 2018.

Kunz dan Barbara. (2010). Pijat Refleksi. Jakarta: PT Grifa Multi Warna

Liana. (2008) Teknik Relaksasi Finger Hold.

www.jarijaritangan.wordpress

Notoamodjo. S. (2014). Metodologi Penelitian Kesehatan. Jakarta: PT Rineka Cipta.

Nursalam, (2010). Konsep dan Penerapan metode penelitian ilmu Keperawatan: pedoman skripsi, tesis, dan instrument penelitian. Jakarta. Salemba Medika.

Pinandita., Dkk. (2012). Jurnal Ilmiah Kesehatan Keperawatan, Volume 8, No. 1, Februari 2012.

$\begin{array}{lrr}\text { Pengaruh } & \text { Teknik } & \text { Relaksasi } \\ \text { Genggam } & \text { Jari } & \text { Terhadap } \\ \text { Penurunan } & \text { Intensitas } & \text { Nyeri Pada } \\ \text { Pasien } & \text { Pasca } & \text { Operasi } \\ \text { Laparatomi } & & \end{array}$

Prasetyo, S. (2010). Konsep dan Proses Keperawatan Nyeri, Yogyakarta: Graha ilmu

Potter, Perry, A.G. (2005). Buku Ajar Fundamental Keperawatan: Konsep, Proses Dan Praktik. Edisi 4. Volume 1. Alih Bahasa: Yasmin Asih, dkk. Jakarta: EGC.

Sabiston, David C. (2010). Buku Ajar Bedah, Jakarta: EGC

Suyanto, Susila, Siswanto. (2016). Metodologi Penelitian Kesehatan dan Kedokteran. Yogyakarta: Bursa Ilmu Karangkajen.

Tulandi (2009). Teori Apendiktomi. Di Akseshttp://id.sribd.com/doc/306 329566/APENDIKTOMI. Pada Tanggal 23 Oktober 2018.

Virgianti N.F. (2015). Penurunan tingkat nyeri pasien post op apendisitis dengan tehnik distraksi nafas dalam, Vol.07(02). P.68-74.

Sulung N, Dian Rani S. (2017). Teknik Rileksasi terhadap intensitas nyeri pada pasien post appendiktomi. Vol.2. p.397. 